\title{
SOME BENNETT-COPSON TYPE INEQUALITIES ON TIME SCALES
}

\author{
S. H. SAKer, R. R. Mahmoud And A. Peterson
}

Abstract. In this paper, we will prove some new dynamic inequalities with two different weighted functions on a time scale. As special cases, the inequalities contain some dynamic inequalities on time scales and also involve some discrete inequalities formulated by Copson, Leindler, Bennett, Chen and Yang. The results will be proved by using Hölder's inequality and Minkowski's inequality on time scales.

Mathematics subject classification (2010): 26D15, 34A40, 34N05, 39A12.

Keywords and phrases: Hardy's type inequality, Copson's inequality, Leindler's inequality, Bennett's inequality, time scales.

\section{REFERENCES}

[1] R. P. Agarwal, M. Bohner And S. H. Saker, Dynamic Littlewood-type inequalities, Proc. Amer. Math. Soc. 143 (2015), 667-677.

[2] R. P. Agarwal, D. O'Regan and S. H. Saker, Dynamic Inequalities on Time Scales, Springer, Heid., 2014.

[3] M. Anwar, R. Bibi, M. Bohner And J. PeČArić, Integral inequalities on time scales via the theory of isotonic linear functionals, Abstr. Appl. Anal. 2011 (2011), 1-16.

[4] G. Bennett, Some elementary inequalities, Quart. J. Math. Oxford (2), 38 (1987), 401-425.

[5] G. Bennett, Some elementary inequalities II, Quart. J. Math. Oxford (2), 39 (1988), 385-400.

[6] M. Bohner And A. Peterson, Dynamic Equations on Time Scales: An Introduction with Applications, Birkhäuser, Boston, Mass, USA, (2001).

[7] M. Bohner, A. Peterson, Advances in Dynamic Equations on Time Scales, Birkhäuser, Boston, 2003.

[8] Q. Chen And B. YAng, On a new reverse Hardy-Littlewood's type inequality, Appl. Math. Sci. 6 (132) (2012), 6553-6561.

[9] A. ČIŽMeŠiJa, J. PeČArić And L.-E. Persson, On strengthened Hardy and Pólya-Knopp's inequalities, J. Approx. Theory 125 (2003), 74-84.

[10] E. T. Copson, Note on series of positive terms, J. Lond. Math. Soc. 3 (1928), 49-51.

[11] E. T. Copson, Some integral inequalities, Proc. Roy. Soc. Edin.: Section A Math. 75 (1976), 157164.

[12] G. H. HARDY, Notes on a theorem of Hilbert, Math. Z. 6 (1920), 314-317.

[13] G. H. HARDY, Notes on some points in the integral calculus, LX. An inequality between integrals, Mess. Math. 54 (1925), 150-156.

[14] G. H. Hardy, J. E. Littlewood and G. Polya, Inequalities, 2nd ED. Cambridge Univ. Press, 1934.

[15] S. HILGER, Analysis on measure chain-a unified approach to continuous and discrete calculus, Results Math. 18 (1990), 18-56.

[16] S. Kaijser, L.-E. Persson And A. Öberg, On Carleman and Knopp's inequalities, J. Approx. Theory 117 (2002), 140-151.

[17] A. Kufner and Lars-Erik Persson, Weighted Inequalities of Hardy Type, World Scientific Publishing (2003).

[18] A. Kufner, L. Maligranda and L. Persson, The Hardy Inequalities: About its History and Some Related Results, Pilsen (2007). 
[19] L. LeIndLER, Generalization of inequalities of Hardy and Littlewood, Acta Sci. Math. (Szeged), 31 (1970), 279-285.

[20] L. LEINDLER, Further sharpening of inequalities of Hardy and Littlewood, Acta Sci. Math. (Szeged), 54 (1990), 285-289.

[21] V. G. MAZ'JA, Sobolev Spaces, Springer-Verlag, Springer Series in Soviet Mathematics (1985).

[22] R. N. Mohapatra And F. L. Salzman, On a result of Leindler, Math. Ineq. Appl. 5 (2002), 39-43.

[23] B. Muckenhoupt, Hardy's inequality with weights, Studia Math. 44 (1972), 31-38.

[24] B. OpIC And A. KufNer, Hardy-type Inequalities, Longman Scientific\& Technical, Harlow, UK (1989).

[25] L. E. Persson AND V. D. Stepanov, Weighted integral inequalities with the geometric mean operator, J. Ineq. Appl. 7 (2002), 727-746.

[26] P. ŘEHÁK, Hardy inequality on time scales and its application to half-linear dynamic equations, J. Ineq. Appl. 5 (2005), 495-507.

[27] S. H. SAKER, Hardy-Leindler type inequalities on time scales, Appl. Math. Inf. Sci. 8 (2014), 29752981.

[28] S. H. SAKER AND D. O'REGAN, Extensions of dynamic inequalities of Hardy's type on time scales, Math. Slovaca (in press).

[29] S. H. SAKER AND J. GRAEF, A new class of dynamic inequalities of Hardy's type on time scales, Dynam. Systems Appl. 23 (2014), 83-93.

[30] S. H. SAKer And D. O'Regan, Hardy and Littlewood inequalities on time scales, Bull. Malays. Math. Sci. Soc. (in press).

[31] S. H. Saker, D. O'Regan And R. P. Agarwal, Some dynamic inequalities of Hardy's type on time scales, Math. Ineq. Appl. 17 (2014), 1183-1199.

[32] S. H. Saker, D. O'Regan And R. P. Agarwal, Generalized Hardy, Copson, Leindler and Bennett inequalities on time scales, Math. Nachr. 287 (2014), 686-698.

[33] S. H. SAKer, D. O'Regan AND R. P. AgARwal, Dynamic inequalities of Hardy and Copson types on time scales, Analysis 34 (2014), 391-402.

[34] S. H. SAKer, D. O'Regan And R. P. Agarwal, Littlewood and Bennett inequalities on time scales, Mediterr. J. Math. 8 (2014), 1-15.

[35] S. H. SAKER, D. O'RegAn AND R. P. AgaRwal, Converses of Copson's inequalities on time scales, Math. Ineq. Appl. 18 (2015), 241-254.

[36] S. H. Saker, R. R. Mahmoud and A. Peterson, Weighted Hardy-type dynamic inequalities on time scales, Mediterr. J. Math. (in press).

[37] G. TAlenti, Sopra una diseguaglianza integrale, Ann. Sc. Norm. Super. Pisa Cl. Sci. 21 (3) (1967), $167-188$.

[38] G. TomaselLi, A class of inequalities, Boll. Unione Mat. Ital. 2 (4) (1969), 622-631. 